\title{
The Development of Competency Model Perceived by Malaysian Human Resource Practitioners' Perspectives
}

\author{
Kahirol Mohd Salleh ${ }^{1}$, Nor Lisa Sulaiman ${ }^{1} \&$ Gene W. Gloeckner ${ }^{2}$ \\ ${ }^{1}$ Faculty of Technical and Vocational Education, University of Tun Hussein Onn Malaysia, Malaysia \\ ${ }^{2}$ School of Education, Colorado State University, Fort Collins, USA \\ Correspondence: Kahirol Mohd Salleh, Faculty of Technical and Vocational Education, University of Tun \\ Hussein Onn Malaysia, Malaysia. E-mail: kahirol@uthm.edu.my
}

Received: September 24, 2014 Accepted: January 29, 2015 Online Published: April 20, 2015

doi:10.5539/ass.v11n10p175

URL: http://dx.doi.org/10.5539/ass.v11n10p175

\begin{abstract}
The intent of this research was to identify Malaysian Human Resource Development (HRD) practitioners' perceptions of competencies needed by HRD practitioners in organizations. The research was based on the American Society for Training and Development (ASTD) models for Workplace Learning and Performance (WLP). The purpose was to assess the perceptions of Malaysian HRD practitioners in organizations regarding the importance of competencies for human resource development in organizational contexts. This study employed quantitative, cross-sectional survey, and an existing ASTD competencies instrument. Organizations were chosen based on the Federation of Malaysian Manufacturer's (FMM) database. Data for this study were collected from 144 HRD practitioners from various organizations in Malaysia who successfully completed the web-based survey. Data were analyzed using descriptive statistics and Exploratory Factor Analysis. The findings of the study indicated that the Malaysian HRD practitioners perceived certain competencies as currently important and others as important in the future for their organization. The results were supported by a number of statistical findings with medium to small effect sizes. By using exploratory factor analysis, this study revealed that the Malaysian HRD practitioners perceived only 25 of the 52 competency items to be important. The results from this study have implications for the ASTD competency model and provide evidence that the competencies needed by employees and in organizations are changing over time.
\end{abstract}

Keywords: competencies, organization performance, human resource development, exploratory factor analysis

\section{Introduction}

As Malaysia moves into the post-industrial era, increasing demands for a supply of competent workers to stress effective education and preparation. To become global players, organizations need to provide workers with new and broader skills than ever before to meet the challenges of today's and tomorrow's workplace. The change in the employment paradigm occurred due to globalization and a better understanding of how competent workers can reduce the costs of operation. According to McKelvey (2009) more employers are expecting their employees to have a college education as a marker of work skill and intellectual abilities. The changes taking place in the workplace pose challenges to workers of all ages with regard both to continuous learning and the updating of competencies (Paloniemi, 2006). Given these circumstances, it has become increasingly valuable for workers to develop and improve their competencies, skills, and work abilities systematically. Siikaniemi (2009) points out that the lack of a competent workforce is an ever-increasing challenge, which requires new ways to manage competence and employability of the personnel. Similarly, Paloneimi (2006) indicates competence and expertise are seen as one of the most valuable resources of individuals, organizations, and societies have indicated indirectly of the challenges surrounding the issues of competencies in the workforce. Therefore, education has been responsive to the needs of human resource development by supplying competent graduates to the workplace. To strengthen education, it is mentioned in the Third Outline Perspective Plan (OPP3), the Malaysian government emphasizes the need for fundamental realignment in the policies and strategies of human resource development for fulfilling the needs of industries (Malaysia Government, 2001). As nations develop, trained workers become indispensable to the achievement of national goals and education receives endorsements and support from the government and industries. Human resource professionals need to play an active and guiding role in enabling organizations to choose its workers well, instill the employees with the proper responsibilities, 
support their growth, and respect their needs to achieve the organization's objectives (Long \& Wan Ismail, 2008).

To ensure that competent workers contribute to human resource development and minimize the competency gap between the academic environment and industrial needs, it is critical to analyze the perceptions of current HRD professionals in regards to their competency level. There is also a need for a high rate of participation of all stakeholders, including government, industries, and others, to close the competency gap and differences in perspectives. Organizations and workers should be aware of and prepared for the transition to workforce competency demands. It is important to narrow the difference gap in needed competencies because it will lead to more training and development for the workers. According to Vakola, Soderquist, and Prastacos (2007), the concept of competency lies in human resources that can provide a basic integration key of human resource activities such as selection and assessment, performance management, training, development and reward management. There are a number of factors that influence change in the workforce including technological advances, changes in business practice, job turnover, and occupational mobility (Campbell, 1997). Thus, flexible training and development programs capable of adapting to the changing demands of the workforce markets can best support competent workers. This, in turn, will keep training and development programs relevant. Broader skill bases and more flexible training and development programs must be encouraged. Training and development programs should embrace the need for restructuring and shift away from the conventional forms of the theory based approach and instead focus more narrowly on work organizations and be more work-based related (Curtain, 1990). Thus, training and development programs in organizations are designed to align with workforce demand.

The ASTD Workplace and Learning Performance competencies model by Rothwell, Sanders, and Soper (1999) was used as a benchmark in this study. The Workplace Learning and Performance (WLP) Model was first introduced by Rothwell in 1996. The model then developed and changed to meet the needs of 23 organizations. In 1999, Rothwell, Sanders, and Soper come out with the latest WLP model. Yoo (1999) pointed out that WLP models are based on four foundations consisting of: human performance improvement, action research model, internal environment, and external environment. It is the most comprehensive human resource development competency study that has been done in the United States. Apart from that, Yoo (1999) stated the ASTD Model for Workplace Learning and Performance is the most comprehensive and condensed HRD model, integrating the six Human Performance Improvement Model, Action Research Model, eight areas of High Performance Workplace, and seven sectors of the External Environment. The model combines all elements from previous studies including workplace, learning, and human performance. This study replicates the study of the 1999 WLP Model and other studies conducted in Asia to provide data and direction to WLP practitioners in Malaysia.

\section{Conceptual Framework}

The conceptual framework of this study is based on the American Society for Training and Development (ASTD) competency model for Workplace Learning and Performance (WLP) developed by Rothwell, Sanders, and Soper (1999). ASTD is the world's professional association and leading resource on WLP subjects. Therefore, the purpose of this conceptual framework is to illustrate the new direction of the HRD field, and to identify the roles and competencies related with workplace learning and performance. Based on the ASTD WLP competency model there are a total of 52 competencies listed from the six categories. These 52 competencies are categorized into six competency groups. Table 1 shows the competency groups and seven WLP roles.

Malaysia needs to look forward to improve the strength of workers' competencies. This can be achieved by adopting and adapting the competencies model concept from the ASTD WLP competency model by Rothwell et al. (1999). However, there are many competency models that could be applied to Malaysian organizations. Part of the challenge is in choosing the right competency model to be applied to Malaysian settings. For this study, the ASTD WLP competency model (see Table 1) was chosen because this model has been used and tested outside of the United States (Yang, 1994; Yoo, 1999; Chen, 2003). This model concept is one of the ways to test and ensure that human resource qualities in Malaysia are enhanced and improved. Many organizations are adopting competency-based models to meet their developing goals and needs (Berge, Verneil, Berge, Davis, \& Smith, 2002). The model also needs to work in conjunction with the organization's policies and vision because it tests the worker's competencies. While there are many competency models that could be applied to a local setting, the model itself needs to be adjusted to meet the purpose. The model can be utilized as a platform for an organization to deduce the best plan for the development of current and future workers. Investing to develop the competency levels of people are one of the most powerful ways to demonstrate to employees that they are genuinely valued, respected, and trusted (Black, 2001). 
Table 1. Six competency groups and seven WLP roles of the WLP competency model

\begin{tabular}{|c|c|}
\hline & Items \\
\hline \multirow{6}{*}{ Six competency groups } & 1. Analytical \\
\hline & 2. Technical \\
\hline & 3. Leadership \\
\hline & 4. Business \\
\hline & 5. Interpersonal \\
\hline & 6. Technological \\
\hline \multirow{7}{*}{ Seven WLP roles } & 1. Manager \\
\hline & 2. Analyst \\
\hline & 3. Intervention Selector \\
\hline & 4. Intervention Designer and Developer \\
\hline & 5. Intervention Implementor \\
\hline & 6. Change leader \\
\hline & 7. Evaluator \\
\hline
\end{tabular}

\section{Purpose of Research}

Homer (2001) argued that workers' skills are probably the most important foundation for organizations because they impact on every aspect of the process. Organizations, especially in Malaysia, have begun to restructure training and development programs at all levels in order to focus on competencies to meet local employers' needs in organizations and competitiveness. According to Siddique (2010), given the fact that Malaysia has faced growing competition from emerging destinations of international trade, it is crucial to enhance national competitiveness through reform and innovations. This would include research, training and development, industrial and commercial, as well as organization needs. However to make all efforts successful, attention must be paid to the organization commitment. This lack of focus has resulted in the poor linkage of training and development programs with employers and in not having a basis for determining or organizing current programs, which focus on needs. Therefore this research is undertaken to seek and identify important relevant aspects in HRD competencies, in line with the needs of the present global job market in terms of human resources. The purpose of this research is to identify Malaysian HRD practitioners' perceptions of necessary competencies needed by HRD practitioners in the organizations, based on the ASTD models for Workplace Learning and Performance (Rothwell, Sanders, \& Soper, 1999). It also aims to assess the perceptions of HRD professionals in organizations regarding the impact and challenge of competencies for human resources development in organizational contexts.

\section{Research Method and Design}

This study was conducted using a fully quantitative research design survey method because the study provides a numeric description of opinion of a population. A survey was determined as an appropriate approach for gathering data and information about the variables in this study because it can be generalized from a sample to a population so that inferences can be made about the same characteristics of the population. This survey design is Cross-sectional because the survey information was collected at one point in time, which reflects current attitudes, opinions, or beliefs (Creswell, 1994). Exploratory Factorial Analysis (EFA) was conducted to check the factor structure of the 52 items in the WLP competencies list. EFA is used to discover and investigate the theoretical construct based on the ASTD WLP Competency Model. EFA also used to investigate the structure and validity of items in this study

The target population for this study is Malaysian human resource development (HRD) practitioners. Since the target population for this study was limited to those who are involved in HRD, the participants were drawn from various HRD/HRM related associates in Malaysia. The designation may vary among organizations. The HRD practitioner's job could include training and development, organization development, management development, career development, or human resource management. The lists of names associated with HRD were gathered from the Federation of Malaysian Manufacturers (FMM). The FMM is a private sector economic organization in Malaysia. Established in 1968, FMM represents over 3,000 manufacturing and industrial service companies. FMM has been recognized as a leading voice of the industry in Malaysia. Therefore, the mailing list consisting of member names of the companies in Malaysia was obtained from the FMM website. The FMM website listed 
approximately 2,400 companies as their members.

\section{Data Analysis}

The data analysis was done in multi-stages and simultaneously with data collection. Standard, non-parametric statistics were used in the initial stage of data analysis for each question. The raw data were coded using a Statistical Package for the Social Sciences (SPSS). A codebook was used to transfer the information into SPSS. It was segregated into various sections based on the research questionnaire such as: descriptive, correlation, regression, and analysis of variance. Descriptive statistics methods were used to analyze the demographic information. Based on the findings, mean, standard deviation and ranking were calculated and tabulated to analyze the characteristics and distribution. Demographic information was divided into two categories, i.e. personal information and organization information. The personal characteristic information questions are questions one through six, and the questions included HRD discipline, current level, years of experience, level of education, age, and gender. The organization characteristic information consists of three questions, including type of business, numbers of employees, and type of organization.

Exploratory Factor Analysis (EFA) is a statistical tool for the investigation whether a number of variables of interest are linearly related to a smaller number of unobservable factors also known as latent variables, or factor. A latent variable is an unobservable variable that is assumed to influence observe variable. Hence, EFA are used to group's variables with similar characteristic together. Apart from that, EFA is also used to assess the reliability and validity of measurement scale. In order to make the interpretation of the factors that are considered relevant, this study applied EFA to evaluated numbers of factor retained to a more manageable number and compared with the previous study. Result from data analysis and findings will help Malaysia HRD professionals to see the relevance of competencies to the world of work, improving the training and development programs, and influencing the future career choices and decisions of future educators. It is hoped that through this research, issues, challenges and recommendations put forward will further enhance better understanding for HRD professionals and the organizations.

\section{Findings}

The analysis of demographics of Malaysian HRD practitioners showed wide variations in background characteristics. These background characteristics were organized into three categories; individual, organization and WLP. In regard to individual profiles, six questions were asked. In terms of discipline, most of the respondents in Malaysia were from Human Resource Management (40.3\%). These findings correspond to published studies, which indicate that a majority of disciplines in Malaysia Human Resource professional are HRM. Most of the respondents in this study were Managers (43.1\%) at the organization level. This shows that most respondents were clustered in decision-making positions and top-level management. In terms of gender, most respondents were male $(60.4 \%)$ while females were 39.6 percent. This result is similar to the overall workforce in the country. According to UNdata (2011), the Malaysian female labor force participation in 2008 was 44.6 percent. For the organization profile, six different questions were asked. The findings showed a balance between the manufacturing sector $(56.3 \%)$ and non-manufacturing sector (43.8\%). The types of businesses for this study were diverse including automotive, construction, telecommunication, finance, and others. The demographic profile of the respondents for this study is shown in Table 2.

The internal consistency reliability for each competency group is measured using Cronbach's Alpha. The overall reliability for the 52 competency items was .96 (Cronbach's Alpha). To further investigate the structure and validity of the items, Exploratory Factorial Analysis (EFA) was conducted. Gliner, Morgan, and Leech (2009) remarked that factor analysis could provide evidence based on internal structure when a construct is complex and several aspects are measured. Therefore, principal axis factor analysis with oblique rotation was conducted to assess the underlying structure for the 52 competencies. Prior to the factors extraction, several tests should be conducted to assess the suitability of the respondents data included Kaiser-Meyer-Olkin (KMO) measure of sampling adequacy. The result of a KMO value was .782, which suggested that there was correlation among items. According to Beavers et al. (2013) the KMO measure of sampling adequacy is a test of a shared variance in the items. They suggested the guideline for assessing the measure (see Table 3). As shown in Table 3, the KMO index ranges from 0 to 1 , with 0.60 considered suitable for factor analysis. EFA then revealed the presence of eleven components with eigenvalues exceeding 1.00. The analysis was done using a scree plot (see Figure 1) with eigenvalues on the $y$-axis and factor numbers on the x-axis. Jackson (1993) suggested that the point where the first few eigenvalues depart from the line distinguishes the interpretable and trivial components. Additionally, Costello and Osborne (2005) point out that the scree plot test involves examining the graph of the eigenvalue and looking for the natural bend or break point in the data where the curve flattens out. Figure 1 displays an 
inspection analysis using a scree plot test, and suggests that three factors may be appropriate for the break point in the data where the curve flattens.

Table 2. Demographic profile of Malaysian human resource development practitioners $(n=144)$

\begin{tabular}{|c|c|c|c|c|c|}
\hline Variables & $\mathbf{n}$ & $\%$ & Variables & $\mathbf{n}$ & $\%$ \\
\hline 1. Discipline & & & 5. Age (years) & & \\
\hline Human Resource Management & 58 & 40.3 & 25 and under & 12 & 8.3 \\
\hline Career Development & 19 & 13.2 & 26 to 35 & 38 & 26.4 \\
\hline Organization Development & 19 & 13.2 & 36 to 45 & 62 & 43.1 \\
\hline Generalist & 15 & 10.4 & 46 to 55 & 28 & 19.4 \\
\hline Management Development & 14 & 9.7 & 56 to 65 & 3 & 2.1 \\
\hline Training & 14 & 9.7 & Over 65 & 1 & 0.7 \\
\hline Other & 5 & 3.5 & Total & 144 & 100 \\
\hline \multirow[t]{2}{*}{ Total } & 144 & 100 & & & \\
\hline & & & 6. Gender & & \\
\hline 2. Current Level in Organization & & & Male & 87 & 60.4 \\
\hline Manager & 62 & 43.1 & Female & 57 & 39.6 \\
\hline Executive & 33 & 22.9 & Total & 144 & 100 \\
\hline Supervisor & 25 & 17.4 & & & \\
\hline Entry & 14 & 9.7 & 7. Primary Type of business & & \\
\hline Private Consultant & 7 & 4.9 & Manufacturing & 81 & 56.3 \\
\hline Other & 3 & 2.1 & Non-manufacturing & 63 & 43.8 \\
\hline Total & 144 & 100 & Total & 144 & 100 \\
\hline 3. Professional Experience (years) & & & 8. Number of Full-time Employees & & \\
\hline Less than 1 year & 15 & 10.4 & Less than 100 & 67 & 46.5 \\
\hline $1-5$ & 42 & 29.2 & $100-199$ & 19 & 13.2 \\
\hline $6-10$ & 41 & 28.5 & $200-299$ & 18 & 12.5 \\
\hline $11-15$ & 24 & 16.7 & $300-399$ & 10 & 6.9 \\
\hline $16-20$ & 14 & 9.7 & $400-499$ & 7 & 4.9 \\
\hline More than 20 years & 8 & 5.6 & 500 or more & 23 & 16.0 \\
\hline Total & 144 & 100 & Total & 144 & 100 \\
\hline 4. Highest Level of Education & & & 9. Type of Organization & & \\
\hline Diploma/ Certificate & 32 & 22.2 & Local company & 91 & 63.2 \\
\hline Bachelors & 79 & 54.9 & International company & 29 & 20.1 \\
\hline Masters & 38 & 18.8 & Global company & 24 & 16.7 \\
\hline Doctoral & 3 & 2.1 & Total & 144 & 100 \\
\hline Other & 3 & 2.1 & & & \\
\hline Total & 144 & 100 & & & \\
\hline
\end{tabular}

*Note: Due to rounding, individual percentage may not add up to 100 percent

Table 3. Interpretation guidelines for Kaiser-Meyer-Olkin test

\begin{tabular}{ll}
\hline KMO Value & Degree of Common Variance \\
\hline 0.90 to 1.00 & Marvelous \\
0.80 to 0.89 & Meritorious \\
0.70 to 0.79 & Middling \\
0.60 to 0.69 & Mediocre \\
0.50 to 0.59 & Miserable \\
0.00 to 0.49 & Unacceptable \\
\hline
\end{tabular}




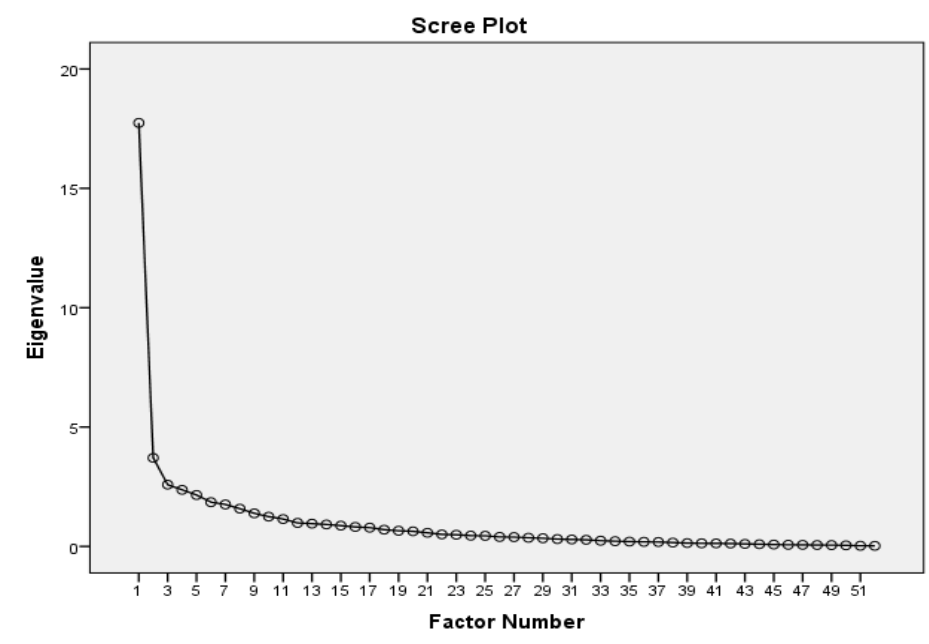

Figure 1. Scree plot for competencies items

Despite this study did not find the same factor structure as a previous study had, three new categories or constructs of the Malaysian HRD Competencies were developed. Three factors were requested based on the fact that the items were shown to index three constructs and consideration of the meaningfulness of a solution. Three factor loadings for the rotated factors, with loadings less than .40 omitted to improve clarity. The communalities for all items were relatively high, between .897 to .744 , and indicated the reliability of the loading factor was strong. After rotation, the first factor accounted for 33.07 percent of the variance, the second factor accounted for 6.14 percent, and the third factor accounted for 4.02 percent. The first factor (Factor 1), appeared to represent Main Competencies where 18 items were loaded. However, after reviewing the items grouping, the researcher decided to reduce the items into ten items that related to the Organizational Competencies. Items that loaded on Factor 2 appeared to represent Sub Competencies 1 where eight items represent the Thinking Competencies. Items that loaded on the Factor 3 appeared to represent Sub Competencies 2 where seven items represent the Application Competencies. A total of 19 items were excluded from this analysis because of the same weight in linear combination of the variables that showed in the pattern matrix. Although the excluded items are helpful in descriptive statistical analyzing, the 19 items are not put into the three identified constructs.

To review the validity of the new items, EFA using principal axis analysis with oblique rotation was conducted one more time. In total eight items from the Main Competencies (Organizational Competencies) were removed because they could not fit with the first construct. The results of the KMO measure of sampling adequacy value was .857 , suggesting that there is correlation between items. Three factors were requested, based on the fact that the items were designed to index three constructs: Main Competencies (Organizational Competencies), Sub Competencies 1 (Thinking Competencies), and Sub Competencies 2 (Application Competencies). After rotation, the first factor accounted for 36.17 percent of the variance, the second factor accounted for 7.59 percent, and the third factor accounted for 6.01 percent. Table 4 displays the new items for the rotated factor, with loading less than .40 omitted to improve clarity. To confirm the numbers of factors in the EFA, Parallel Analysis and Minimum Average Partial (MAP) was conducted. The results from parallel analysis and minimum average partial suggested that three factors occurred. According to Watkins (2006), parallel analysis is one of the most accurate guides for determining the number of factors to extract in EFA.

The new constructs are Main Competencies representing Organizational Competencies, Sub Competencies 1 representing Thinking Competencies, and Sub Competencies 2 representing Application Competencies. Figure 2 illustrated the integrated competency model for HRD practitioners in Malaysia. Sherman (2004) remarks that the competency model looks at the role of an individual in the organization. The numbers of competencies were reduced from 52 to 25 items. The new competency groups represent the current and future competencies perceived important by the Malaysian HRD practitioners. The Malaysian HRD Competencies Model shows the relationship between Main Competencies and two Sub Competencies groups. The three competency groups are skill sets acquired by the practitioners. Table 4 shows the competency groups based on the three new constructs and their relationship. Similarly, in the literature review and in the Bernthal et al. (2004) findings on the ASTD 2004 competency study, the items in the competencies list were reduced over time. In the ASTD 2004 
competency study the foundation of competencies were divided into three categories: interpersonal items, business/management items, and personal items. In total, there were 12 competency items in the ASTD 2004 competencies study.

Table 4. Factorial loadings for the rotated factors for main competencies, sub competencies 1 , and sub competencies 2

\begin{tabular}{|c|c|c|c|c|}
\hline \multirow[b]{2}{*}{ Scale Items } & \multicolumn{3}{|c|}{ Factor Loadings } & \multirow[b]{2}{*}{ Communality } \\
\hline & $\begin{array}{l}\text { Main } \\
\text { Comp }\end{array}$ & $\begin{array}{l}\text { Sub } \\
\text { Comp1 }\end{array}$ & $\begin{array}{l}\text { Sub } \\
\text { Comp } 2\end{array}$ & \\
\hline Identification of Critical Business Issues & 0.692 & & & 0.585 \\
\hline Communication & 0.645 & & & 0.608 \\
\hline Group Dynamics & 0.629 & & & 0.564 \\
\hline Work Environment Analysis & 0.589 & & & 0.517 \\
\hline Goal Implementation & 0.583 & & & 0.627 \\
\hline Buy-in/Advocacy & 0.569 & & & 0.575 \\
\hline Consulting & 0.567 & & & 0.575 \\
\hline Negotiating/Contracting & 0.561 & & & 0.466 \\
\hline Systems Thinking & 0.555 & & & 0.669 \\
\hline Visioning & 0.448 & & & 0.589 \\
\hline $\begin{array}{l}\text { Workplace Performance, Learning Strategies, and } \\
\text { Intervention Evaluation }\end{array}$ & & 0.732 & & 0.655 \\
\hline Competency Identification & & 0.707 & & 0.662 \\
\hline Facilitation & & 0.679 & & 0.646 \\
\hline Standard Identification & & 0.667 & & 0.543 \\
\hline Questioning & & 0.628 & & 0.635 \\
\hline Model Building & & 0.572 & & 0.597 \\
\hline Analytical Thinking & & 0.562 & & 0.523 \\
\hline Leadership & & 0.462 & & 0.658 \\
\hline Staff Selection Theory and Application & & & -0.774 & 0.689 \\
\hline Training Theory and Application & & & -0.761 & 0.705 \\
\hline Feedback & & & -0.617 & 0.690 \\
\hline Reward system theory and Application & & & -0.539 & 0.724 \\
\hline Organization Development Theory and Application & & & -0.483 & 0.619 \\
\hline Career Development Theory and Application & & & -0.474 & 0.716 \\
\hline Process Consultation & & & -0.447 & 0.701 \\
\hline Eigenvalues & 9.04 & 1.90 & 1.50 & \\
\hline$\%$ of variance & 36.17 & 7.59 & 6.01 & \\
\hline
\end{tabular}

Note. Loadings $<.40$ are omitted

The elements of the competency model for Malaysian HRD practitioners in Figure 1 are consistent with the literature describing competency models. Rothwell (2002) remarked that there are core competencies required for all workers including knowledge, skills, and abilities. Organizational competencies are more about comprehension, articulation, and a combination of skill, attitudes, knowledge, and employee behavior needed in an organization. Similarly, Sherman (2004) indicated that competencies are the combination of knowledge, abilities, personal attributes, and skills that contribute to individual and organizational performance. Based on the research finding, Organizational competencies are considered essential for employees regardless of their roles, level, and discipline in the organization. It links an organization's essential values, mission, and vision to the employees. Organizational competencies are also an effective performance tool, as well as a necessary guide for development process in organizations. It is the most important competencies to reinforce the two other sub competencies in the organization. 


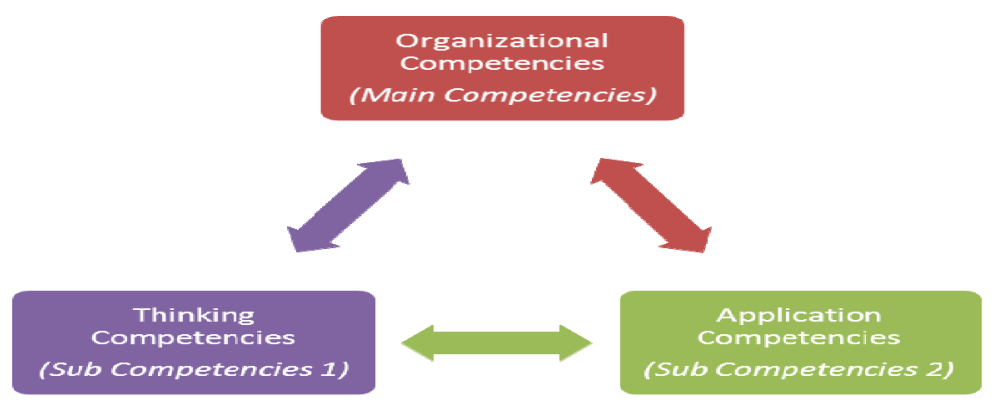

Figure 2. Competency model for Malaysian HRD practitioners

Conversely, the finding has shown that thinking competencies are more related to skill and knowledge (see Table 5). Thinking competencies are most effective in support long-term planning in regards to the employees' professional and career development process in an organization. Thinking competencies can help employees develop and generate better ideas, processes, and approaches that shape the organization. Application competencies are more about attitudes and behavior. Similarly, the result of this research has shown that Application competencies help employees understand the right attitudes, morale, values, and behavior that are needed for an organization (see Table 5). It is also related to the employee's level of satisfaction and motivation in the organization. Overall, the combination of these three competencies in organizations should enhance workers competency and organizational performance. This study revealed that in most organizations in Malaysia, only a few competencies can draw out potentially useful skills, attitudes, knowledge, or behavior from employees. As a result (Table 5), only 25 competencies from the original 52 competencies that were tested are perceived important to the HRD practitioners in Malaysia when factor analyzed.

Table 5. Three competency groups for Malaysian HRD practitioners

\begin{tabular}{|c|c|}
\hline Competency Group & Competency Description \\
\hline \multirow{10}{*}{$\begin{array}{l}\text { Organizational Competencies } \\
\text { (Main Competencies) }\end{array}$} & 1. Identification of Critical Business Issues \\
\hline & 2. Communication \\
\hline & 3. Group Dynamics \\
\hline & 4. Work Environment Analysis \\
\hline & 5. Goal Implementation \\
\hline & 6. Buy-in/Advocacy \\
\hline & 7. Consulting \\
\hline & 8. Negotiating/Contracting \\
\hline & 9. Systems Thinking \\
\hline & 10. Visioning \\
\hline \multirow{8}{*}{$\begin{array}{l}\text { Thinking Competencies } \\
\text { (Sub Competencies 1) }\end{array}$} & 1. Workplace Performance, Learning Strategies, and Intervention Evaluation \\
\hline & 2. Competency Identification \\
\hline & 3. Facilitation \\
\hline & 4. Standard Identification \\
\hline & 5. Questioning \\
\hline & 6. Model Building \\
\hline & 7. Analytical Thinking \\
\hline & 8. Leadership \\
\hline \multirow{7}{*}{$\begin{array}{l}\text { Application Competencies } \\
\text { (Sub Competencies 2) }\end{array}$} & 1. Staff Selection Theory and Application \\
\hline & 2. Training Theory and Application \\
\hline & 3. Feedback \\
\hline & 4. Reward System Theory and Application \\
\hline & 5. Organization Development Theory and Application \\
\hline & 6. Career Development Theory and Application \\
\hline & 7. Process Consultation \\
\hline
\end{tabular}




\section{Discussion and Implication}

The findings revealed that Malaysian HRD practitioners perceived that competencies are important to the organization. The findings are similar to what is reported in the literature review (Chen, 2003; Peerapornvitoon, 1999; Yoo, 1999) which identified the significant competencies. In contrast, the perceived importance of competencies is changing based on the respondent demographics and organizational culture. While much of the literature on organizational performance emphasizes the importance of competencies, there is little evidence that connects competencies with organizational culture. Rather, competencies can lead organizational change and improve overall performance. Rothwell, Sanders, and Soper (1999) argued that the challenge for the WLP profession is in assessing the skills and knowledge that WLP practitioners would need in the future. It is important to view the research findings or output with content on how employees learn. Rothwell (2002) saw this by saying how important it is to emphasize that competencies are focused on how people learn, not on what they learn.

Learning process plays an important role in any organization since making change is not an easy one. In regards to the learning process, the findings showed that Malaysian HRD practitioners are still far behind others. To keep up with the change, Malaysian HRD practitioners need to be exposed to new challenges and interventions in human resources. Bernthal et al. (2004) listed eight trends that are shaping the future in human resources for WLP professionals; (1) drastic times, drastic measures; (2) blurred lines - life or work?; (3) small world and shrinking; (4) new faces, new expectations; (5) work be nimble, work be quick; (6) security alert!; (7) life and work in the E-lane; and (8) a higher ethical bar. As work environments and demands change, competencies will be adapted to fit those changes. Thus, it is an opportunity for HRD practitioners in Malaysia to study these eight trends in their own organization and identify the competency gap, not only between departments or units but also across other organizations. Once the organization understands the required competencies, HRD practitioners can determine the combination of competencies needed by employees in their organizations.

The findings also revealed that competencies are a key to aligning human resource development with organization performance. Organizations that operate in highly competitive environments must be flexible and able to react quickly to market changes, such as demand for competent and knowledgeable workers. It is vital for HRD practitioners to allocate time, energy, and resources to plan for the organization development process and implementation of competency in organizations. Cummings and Worley (2005) saw organization development as a process that applies behavioral science knowledge and practices to help organizations build the capacity to change and to achieve greater effectiveness, including increased financial performance and improved quality of work life. Additionally, Estep (2008) pointed out that organizational development is a value based approach to systems change in organizations and that it strives to build the capacity to achieve and sustain the new desired state that benefits the organization. Thus, an organization development process will help HRD practitioners to the performance of organization by determining the changing process and keeping track of necessary improvements.

Organization development is an ongoing process of revision, re-organizing, and development that should be inherent to every organization. If the organizational development process is used systematically, an organization may be more likely to adapt to a new change and create its own organizational culture consistent with higher performance. Sherman (2004) suggested that organizations develop competencies to provide their employees with a framework that allows them to find opportunities to grow in their current assignment, thereby adding more value to the organization.

\section{Conclusion}

This study supports the idea that competencies are keys for organizational performance. Based on the findings of the study, many conclusions can be drawn. While the research did not reveal many relationships of statistical significance, the practical implications are many. The findings suggest that competencies have an implication for the organizational development process. Competencies can improve organizational development and performance when collectively implemented by the organization. Rothwell (1999) remarked that a lack of skills and knowledge contributes to substandard performance in organizations. This study provided clarification that competencies need to have a direction and foundation in the workplace. In contrast, the lack of clarity and understanding about competencies makes HRD practitioners unable to determine which competencies are perceived important for the workers in the organization. Carter (2001) argued that for an organization to gauge employee competency, organizations must know whether the knowledge, skills, and abilities are measured accurately. The analysis in this study did support some of the findings reported in the literature review regarding competencies needed by the employees in an organization. 
This study reported findings that are meaningful for Malaysian organizations. Clearly, the 52 items in the competencies list is too broad. The analysis in the Exploratory Factorial Analysis revealed that only 25 competencies are important in Malaysian organizations. It is an indication of the progression that happens to competencies, and this situation is different across organizations and geographical areas. ASTD has already made a revision to the competencies list in an ASTD 2004 competency study. Researchers (Chen, 2003; Peerapornvitoon, 1999; Yoo, 1999) use the ASTD competencies model as a benchmark to study competency and have encountered changes over time. In an organizational context, competencies are arguably often perceived to be a process of learning for individuals, knowledge, and support for HRD practitioners, and development for organizational performance. According to Burke (2008), within the organizational context, change is a process that occurs in organizations, and for the most part, is unplanned and gradual.

This study demonstrated that competencies are important in a variety of ways for employees and organizations. Assessing competencies are one of the most effective tools and approaches for the organization's workers to be in the right. Whiddett and Hollyforde (2003) argued that competencies make an important contribution to performance review because they help structure and standardize discussions about how a person goes about doing his or her job. Moreover, the competencies focus more on employees and organizational performances. Once the organization has the employees in the right positions and roles, the organization has opportunities to set future career development. Having clearly defined competencies also makes employees more effective and reduces job timelines.

In conclusion, the findings of this study suggest that HRD practitioners could perceive the importance of competencies in regard to employee's development process and organizational performance. Competencies involve an ongoing process that fosters employee skills, attitudes, knowledge, and behavior in organizations. There is no absolute answer for the most essential competencies needed by employees and organizations because related skills and knowledge to competencies continue to increase in response to technological advancement. As the technology progresses, the demand for new competencies is grow, and the need to revise competencies is already present. Further research is required to see the impact of current competencies and if the competencies from five years ago are still in demand.

\section{References}

Beavers, A. S., Lounsbury, J. W., Richards, J. K., Huck, S. W., Skolits, G. J., \& Esquivel, S. L. (2013). Practical considerations for using Exploratory Factor Analysis in educational research. Practical Assessment, Research \& Evaluation, 18(6), 1-13.

Berge, Z., Verneil, M. D., Berge, N., Davis, L., \& Smith, D. (2002). The increasing scope of training and development competency. Benchmarking: An International Journal, 9(1), 43-61. http://dx.doi.org/10.11 08/14635770210418579

Bernthal, P. R., Colteryahn, K., Davis, P., Naughton, J., Rothwell, W. J., \& Wellins, R. (2004). ASTD 2004 competency study: Mapping the future. Alexandria, VA: American Society for Training and Development.

Black, D. A. (2001). Creating strategic plans with the power to win. Strategy and Leadership, 29(1), 27-32. http://dx.doi.org/10.1108/10878570110367150

Burke, W. W. (2008). Organization change: Theory and Practice. Thousand Oaks, CA: Sage Publications.

Campbell, C. P. (1997). Workforce requirement: The basis for relevant occupational training. Journal of European Industrial Training, 21(8), 279-297. http://dx.doi.org/10.1108/03090599710184662

Carter, S. D. (2001). The intersection of training and careers: An examination of trends of vocational and professional certification and a call for future research. In R. B. Poell (Eds.), Cutting edge: outstanding paper from 2001 (pp. 48-56). St. Paul, MN: Academy of Human Resource Development.

Chen, A. S. (2003). Perceptions of Taiwan practitioners on expertise level and importance of workplace learning and performance (WLP) competencies. Available from ProQuest Dissertations and Theses database. (UMI No. 3106217).

Costello, A. B., \& Osborne, J. W. (2005). Best practices in exploratory factor analysis: Four recommendations for getting the most from your analysis. Practical Assessment, Research \& Evaluation, 10(7).

Creswell, J. W. (1994). Research design: Qualitative and quantitative approaches. Thousand Oaks, CA: Sage Publications.

Cummings, T., \& Worley, C. (2005). Developing and assisting members. In Cummings, \& Worley (Eds.), Organization Development and Change (pp. 396-416). The United States: South-Western.

Curtain, R. (1990). How to identify skills for award-restructuring purpose, using a modified DACUM technique. 
Asia Pacific Human Resource Management, 28(4), 112-125. http://dx.doi.org/10.1177/10384111900 2800412

Estep, T. (2008). The evolution of the training profession. In E. Biech (Ed.), ASTD handbook for Workplace Learning Professionals. ASTD Press.

Gliner, J. A., Morgan, G. A., \& Leech, N. L. (2009). Research method in applied settings: An integrated approach to design and analysis (2nd ed.). New York, NY: Routledge.

Homer, M. (2001). Skills and competency management. Industrial and Commercial Training, 33(2), 58-62. http://dx.doi.org/10.1108/00197850110385624

Jackson, D. A. (1993). Stopping rules in principal component analysis: A comparison of heuristical and statistical approaches. Ecology, 74(8), 2204-2214. http://dx.doi.org/10.2307/1939574

Long, C. S., \& Wan Ismail, W. K. (2008). Understanding the relationship of HR competencies \& roles of Malaysian human resource professionals. European Journal of Social Sciences, 7(1), 88-103.

Malaysia Government. (2001). The Third Outline Perspective Plan, 2001-2010. Kuala Lumpur, Malaysia: Economic Planning Unit, Prime Minister's Department.

McKelvey, J. B. (2009). Globalization and ageing workers: Constructing a global life course. International Journal of Sociology and Social Policy, 29(1/2), 49-59. http://dx.doi.org/10.1108/01443330910934718

Paloniemi, S. (2006). Experience, competence and workplace learning. Journal of Workplace Learning, 18(7/8), 439-450. http://dx.doi.org/10.1108/13665620610693006

Peerapornvitoon, M. (1999). A survey of workplace learning and performance: Competencies and roles for practitioners in Thailand. Available from ProQuest Dissertations and Theses database. (UMI No. 9940930).

Rothwell, W. J. (2002). The workplace learner: How to align training initiatives with individual learning competencies. New York, NY: AMACOM.

Rothwell, W. J. (Ed.). (1999). ASTD models for Human Performance Improvement (2nd ed.). Alexandria, VA: ASTD Press.

Rothwell, W. J., Sanders, E. S., \& Soper, J. G. (1999). ASTD models for workplace learning and performance. Alexandria, VA: American Society for Training and Development.

Sherman, G. (2004). Competency based HRM: A strategic resource for competency mapping. New Delhi, India: Tata McGraw-Hill.

Siddique, N. A. (2010). Managing for results: Lesson from public management reform in Malaysia. International Journal of Public Sector Management, 23(1), 38-53. http://dx.doi.org/10.1108/09513551011012312

Siikaniemi, L. (2009). Competence and employment forum: Linking HRD and HRM. Journal of European Industrial Training, 33(5), 401-418. http://dx.doi.org/10.1108/03090590910966562

UNdata. (2011). Malaysia country profile. Retrieved from http://data.un.org/Default.aspx

Vakola, M., Soderquist, K. E., \& Prastacos, G. P. (2007). Competency management in support of organizational change. International Journal of Manpower, 28(3/4), 260-275. http://dx.doi.org/10.1108/014377207107 55245

Watkins, M. W. (2006). Determining parallel analysis criteria. Journal of Modern Applied Statistical Methods, $5(2), 344-346$.

Whiddett, S., \& Hollyforde, S. (2003). A practical guide to competencies: How to enhance individual and organizational performance. London, UK: CIPD House.

Yang, J. C. (1994). Perceived competencies needed by HRD managers in Korean. Available from ProQuest Dissertations and Theses database. (UMI No. 9505448).

Yoo, P. J. (1999). Korean human resource development (HRD) practitioners' perceptions of expertise levels and the importance of workplace learning and performance (WLP) competencies. Available from ProQuest Dissertations and Theses database. (UMI No. 9960692).

\section{Copyrights}

Copyright for this article is retained by the author(s), with first publication rights granted to the journal.

This is an open-access article distributed under the terms and conditions of the Creative Commons Attribution license (http://creativecommons.org/licenses/by/3.0/). 